\title{
Scutellaria baicalensis Georgi induces caspase-dependent apoptosis via mitogen activated protein kinase activation and the generation of reactive oxygen species signaling pathways in MCF-7 breast cancer cells
}

\author{
JIN RYEONG PARK ${ }^{1,2}$, MIN CHEOL LEE ${ }^{1,2}$, SEONG-CHEOL MOON ${ }^{2,3}$, JUNGHOON KIM ${ }^{2,4}$, \\ KI-TAE HA ${ }^{2,3}$, EUN JUNG PARK ${ }^{5}$, CHANSIK HONG ${ }^{6}$, BYOUNG-DO SEO ${ }^{7}$ and BYUNG JOO KIM ${ }^{1,2}$ \\ ${ }^{1}$ Division of Longevity and Biofunctional Medicine; ${ }^{2}$ Healthy Aging Korean Medical Research Center; ${ }^{3}$ Division of \\ Applied Medicine; ${ }^{4}$ Division of Pharmacology, Pusan National University School of Korean Medicine, \\ Yangsan 50612; ${ }^{5}$ Department of Physiology, Seoul National University College of Medicine, Seoul 110-799; ${ }^{6}$ Department of \\ Physiology, Chosun University College of Medicine, Gwangju 61452; ${ }^{7}$ Department of Physical Therapy, \\ Kyungwoon University College of Health, Gumi 730-739, Republic of Korea
}

Received November 1, 2016; Accepted April 28, 2017

DOI: $10.3892 / \mathrm{mmr} .2017 .6798$

\begin{abstract}
Scutellaria baicalensis Georgi extract (SBGE) is used in traditional herbal medicine and has also been used clinically to ameliorate the symptoms of various inflammatory diseases and cancer. In women, breast cancer is one of the most common diseases and numerous women succumb to it. The present study was undertaken to investigate the mechanism responsible for the SBGE-induced apoptosis of MCF-7 human breast cancer cells. SBGE was administered to cells at concentrations between 100 and $500 \mathrm{mg} / \mathrm{ml}$, and cell viabilities were identified using an MTT assay. B-cell lymphoma 2 (Bcl-2) and $\mathrm{Bcl}-2 \mathrm{X}$-associated protein (Bax) family members were identified by western blotting, and the mRNA expression levels of the pro-apoptosis genes Fas, Fas ligand (FasL) and tumor necrosis factor (TNF)- $\alpha$ were assessed by reverse transcription-polymerase chain reaction. It was identified that SBGE treatment for $24 \mathrm{~h}$ inhibited MCF-7 proliferation and increased the sub-G1 phase ratio. SBGE suppressed mitochondrial membrane potentials and SBGE-induced apoptotic cell death was identified to be associated with downregulation of $\mathrm{Bcl}-2$, but upregulation of Bax. SBGE-activated caspases 3 and 9, and increased reactive oxygen species generation. However, SBGE had no effect on the expression levels of Fas, FasL or TNF- $\alpha$. Furthermore,
\end{abstract}

Correspondence to: Professor Byung Joo Kim, Division of Longevity and Biofunctional Medicine, Pusan National University School of Korean Medicine, 49 Busandaehakro, Yangsan 50612, Republic of Korea

E-mail: vision@pusan.ac.kr

Key words: Scutellaria baicalensis Georgi, apoptosis, breast cancer, MCF-7 mitogen-activated protein kinase and C-Jun N-terminal kinase inhibitors inhibited SBGE-induced cell death. These results suggested that $\mathrm{SBGE}$ be considered as an agent for the treatment of breast cancer.

\section{Introduction}

Breast cancer is the most common malignant disease in women (1) and accounts for $\sim 25 \%$ of cancer cases $(2,3)$. Despite the number of breast cancer medicines, the prognosis of breast cancer remains poor (4). The main approaches used to treat breast cancer are surgery, radiotherapy, chemotherapy, hormone therapy and targeted therapy (5). However, recovery rates following application of these conventional methods are only $60-80 \%$ for primary cancer and $\sim 50 \%$ for metastatic cancer $(5,6)$.

Traditional Chinese medicine (TCM) has been used to treat various cancers (7). Scutellaria baicalensis Georgi (SBG) is a well-known TCM and is traditionally described as possessing 'heat-clearing, dampness-drying, fire-purging, detoxicating and hemostasis-maintaining' properties (8). In the modern era, it has been demonstrated to possess various properties, including antioxidant and anti-inflammatory effects $(9,10)$, and to inhibit the proliferations of several tumors via apoptosis pathways (11-15). For example, SBG induces the apoptosis of human bladder 5637 cancer cells via the reactive oxygen species (ROS)-dependent activation of caspases (11), inhibits the spread of B16F10 mouse melanoma cells by inactivating the phosphoinositide 3-kinase (PI3K)/protein kinase B (Akt) signaling pathway (12), suppresses the proliferation of ovarian cancer cells by suppressing the p38 mitogen-activated protein kinases (MAPK)-dependent pathway (13), inhibits the growth of human MCF10A cells via transforming epithelial-mesenchymal transition (14) and has been reported to inhibit pulmonary tumor metastasis by impairing the activations of MAPK and PI3K-Akt (15). 
Apoptosis is one of the processes of programmed cell death with specific morphologic characteristics and biochemical features, including membrane blebbing, intracellular fragmentation associated with membrane enclosed cellular fragments (apoptotic bodies) and cellular shrinkage $(16,17)$. Apoptosis-associated molecules serve key roles in the maintenance of physiological homeostasis, but can be abnormally expressed during tumor development $(18,19)$. However, the effects of SBG on MCF-7 human breast adenocarcinoma cells have not been previously investigated. Therefore, the present study aimed to identify the mechanism responsible for the SBG-induced apoptosis of MCF-7 human breast cancer cells.

\section{Materials and methods}

Preparation of $S B G$ extract (SBGE). Baicalin and wogonin were purchased from Wako Pure Chemical Industries Ltd. (Osaka, Japan). Acetonitrile, methanol and water of high performance liquid chromatography (HPLC)-grade were obtained from Avantor Performance Materials (Center Valley, PA, USA). Trifluoroacetic acid was purchased from Sigma-Aldrich (Merck KGaA, Darmstadt, Germany). Accurately weighed standard compounds were dissolved in methanol and diluted. SBGE was obtained from the plant extract bank at the Korea Research Institute of Bioscience and Biotechnology (cat. no. CA04-087; Daejeon, Republic of Korea). SBGE was dissolved in methanol and then filtered through a $0.2 \mathrm{~mm}$ syringe filter (Biofact Co., Ltd., Daejeon, Korea) prior to injection into the HPLC apparatus. The HPLC system used was an Agilent 1200 (Agilent Technologies, Inc., Santa Clara, CA, USA) equipped with a quaternary pump, autosampler, column oven and diode-array detector. HPLC data were acquired using Chemstation software (version B.03.02; Agilent Technologies, Inc.). Chromatographic separation was performed on a XDB $\mathrm{C}_{18}$ column $(4.6 \times 150 \mathrm{~mm}$, $5 \mu \mathrm{m}$; Agilent Technologies, Inc.) at $35^{\circ} \mathrm{C}$. The mobile phase consisted of water containing $0.1 \%$ trifluoroacetic acid and acetonitrile and the chromatographic gradient program was: $20 \%$ acetonitrile for $2 \mathrm{~min}, 20-60 \%$ acetonitrile from 2 to $10 \mathrm{~min}$ and held for $1 \mathrm{~min}$. The column was then re-equilibrated with $20 \%$ acetonitrile. The flow rate was set at $0.8 \mathrm{ml} / \mathrm{min}$ and the injection volume used was $5 \mu \mathrm{l}$. Baicalin and wogonin were detected at $280 \mathrm{~nm}$.

Cell culture and reagents. MCF-7 cells (human breast adenocarcinoma cells) were established at the Cancer Research Center, Seoul National University College of Medicine (Seoul, Republic of Korea). Cells were cultured in RPMI-1640 medium (Gibco; Thermo Fisher Scientific, Inc., Waltham, MA, USA) supplemented with $10 \%$ heat-inactivated fetal bovine serum (Invitrogen; Thermo Fisher Scientific, Inc.) and $20 \mu \mathrm{g} / \mathrm{ml}$ penicillin/streptomycin (Invitrogen; Thermo Fisher Scientific, Inc.) in a $5 \% \mathrm{CO}_{2}$ atmosphere at $37^{\circ} \mathrm{C}$. SP600125 and PD98059 were purchased from Tocris Bioscience (Bristol, UK). All other reagents were supplied by Sigma-Aldrich (Merck KGaA).

Cell viability assay. Cell viability was checked using an assay. MCF-7 cells were treated with $100 \mu \mathrm{l}$ MTT solution $(5 \mathrm{mg} / \mathrm{ml}$ in PBS per well) and incubated for $4 \mathrm{~h}$ at $37^{\circ} \mathrm{C}$. The absorbance was measured at a wavelength of $570 \mathrm{~nm}$ using a microplate reader (Molecular Devices, LLC, Sunnyvale, CA, USA).

Measurement of cell cycle. MCF-7 cells were placed in an Eppendorf tube and ethyl alcohol was slowly added with vortexing. Tubes were then sealed with parafilm and incubated at $4^{\circ} \mathrm{C}$ overnight. Samples were centrifuged for $5 \mathrm{~min}$ at $110 \times \mathrm{g}$ at $4^{\circ} \mathrm{C}$ and supernatants was aspirated and discarded. Cell pellets were resuspended in $200 \mu \mathrm{l}$ propidium iodine (PI) staining solution [PI $(5 \mathrm{mg} / \mathrm{ml} ; 2 \mu \mathrm{l})$ containing RNase $(2 \mu \mathrm{l}$ in PBS $196 \mu 1)](20,21)$ and then centrifuged at 20,000 x g for $10 \mathrm{sec}$ at $4^{\circ} \mathrm{C}$. Following an incubation for $30 \mathrm{~min}$ in the dark at room temperature, samples were analyzed using a fluorescence-activated cell sorter (FACScan; BD Biosciences, Franklin Lakes, NJ, USA) at $488 \mathrm{~nm}$ using Cell-Quest Pro software (version 5.1; BD Biosciences).

Tetramethylrhodamine (TMRM) mitochondrial membrane potential (MMP) assay. To measure MMP, MCF-7 cells were incubated with $25 \mathrm{nM}$ TMRM for $1 \mathrm{~h}$, mounted on a coverslide in a chamber filled with complete culture medium and incubated at $37^{\circ} \mathrm{C}$ in a cell culture incubator. Fluorescent images of samples were observed and captured using a fluorescence microscope at excitation/emission wavelengths of 549/575 nm. The fluorescent intensities of images were measured using ImageJ v1.62 software (National Institutes of Health, Bethesda, MD, USA) and values were expressed as percentages of controls.

Western blot analysis. Western blotting was performed using the lysates of $5 \times 10^{6} \mathrm{MCF}-7$ cells. Briefly, total proteins were extracted using radioimmunoprecipitation assay buffer (Cell Signaling Technology, Inc., Danvers, MA, USA) containing a protease inhibitor cocktail (cat. no. \#5871; Cell Signaling Technology, Inc.). The samples were centrifuged at $18,000 \mathrm{x} \mathrm{g}$ and $4{ }^{\circ} \mathrm{C}$ for $1 \mathrm{~min}$, and protein concentrations were determined using the Bio-Rad Protein Assay kit II (Bio-Rad Laboratories, Inc., Hercules, CA, USA). Equal amounts $(20 \mu \mathrm{g})$ of protein from each sample were separated by $10 \%$ SDS-PAGE, transferred to a PVDF membrane and blocked with 5\% non-fat dry milk at room temperature for $1 \mathrm{~h}$. The membranes were washed twice with Tris-buffered saline containing $0.1 \%$ Tween-20 (TBS-T) and incubated with specific primary antibodies against target proteins, including B-cell lymphoma 2 (Bcl-2; cat. no. NB100-56098; Novus Biologicals, LLC, Littleton, CO, USA), Bcl-2 X associated protein (Bax; cat. no. NB100-65095; Novus Biologicals, LLC), GAPDH (cat. no. sc-32233; Santa Cruz Biotechnology, Inc., Dallas, TX, USA) and $\beta$-actin (cat. no. A2066; Sigma-Aldrich; Merck KGaA) antibodies, diluted to $1: 100$ with $5 \%$ skim milk at $4^{\circ} \mathrm{C}$ overnight. The membranes were rinsed twice with TBS-T and incubated with the appropriate secondary horseradish peroxidase-conjugated antibodies, including rat anti-rabbit IgG (cat. no. sc-2004; Santa Cruz Biotechnology, Inc.) and rabbit anti-mouse IgG (cat. no. Ab6728; Abcam, Cambridge, MA, USA) diluted to 1:1,000 with $5 \%$ skim milk, at room temperature for $1 \mathrm{~h}$. The bands for proteins of interest were detected using the ECL Plus Western Blotting Detection Reagent (GE Healthcare Life Sciences, Pittsburgh, PA, USA) according to manufacturer's instructions. 
Reverse transcription-polymerase chain reaction (RT-PCR) analysis. Total RNAs were isolated from cells using TRIzol reagent (Invitrogen; Thermo Fisher Scientific, Inc.) and equal amounts of RNA ( $2 \mu \mathrm{g})$ were converted to cDNA using AccuPower RT-PreMix (Bioneer Corporation, Daejeon, Korea) at $70^{\circ} \mathrm{C}$ for $5 \mathrm{~min}, 42^{\circ} \mathrm{C}$ for $1 \mathrm{~h}$ and $94^{\circ} \mathrm{C}$ for $5 \mathrm{~min}$ using oligo-dT primers. Specific DNA sequences were amplified using AccuPower PCR-PreMix (Bioneer Corporation) under the following thermocycling conditions: An initial denaturation at $95^{\circ} \mathrm{C}$ for $5 \mathrm{~min}$, followed by 30 cycles of denaturation for $30 \mathrm{sec}$ at $95^{\circ} \mathrm{C}$, annealing for $30 \mathrm{sec}$ at $60^{\circ} \mathrm{C}$ and extension for $30 \mathrm{sec}$ at $72^{\circ} \mathrm{C}$, with a final extension for $10 \mathrm{~min}$ at $72^{\circ} \mathrm{C}$. The PCR primers used in this study were as follows: oligo-dT, 5'-TTTTTTTTTTTTTTTTTTTT-3' reverse; Fas, 5'-ATGCTGGGCATCTGGACCCTCCTA-3' forward and 5'-TCTGCACTTGGTATTCTGGGTCCG-3' reverse; Fas ligand (FasL), 5'-ACTTCCGGGGTCAATCTT GC-3' forward and 5'-TAGAACATCTCGGTGCCTGTA-3' reverse; tumor necrosis factor (TNF)- $\alpha, 5^{\prime}$-GTGGACGAG AGTGTCTGACT-3' forward and 5'-AGCCATCCTGCTTCC TTCCA-3' reverse; and $\beta$-actin 5'-CAAGAGATGGCCACG GCTGCT-3' forward and 5'-TCCTTCTGCATCCTGTCG GCA-3' reverse. Amplified products were analyzed in $1.0 \%$ agarose gels under UV light and images were captured using the GelDoc-It TS Imaging system (UVP, Inc., Upland, CA, USA).

Caspase assay. Caspase 3 and 9 assay kits (BioMol Cellular Activity Assay Kit Plus, Enzo Life Sciences, Inc., Farmingdale, NY, USA) were used. Cells were centrifuged at $1,000 \mathrm{x}$ g at $4^{\circ} \mathrm{C}$ for $10 \mathrm{~min}$, washed with PBS and resuspended in ice-cold cell lysis buffer. Samples were then centrifuged at $10,000 \mathrm{xg}$ for $10 \mathrm{~min}$ at $4{ }^{\circ} \mathrm{C}$ and supernatants were removed. Supernatant samples $(10 \mu \mathrm{l})$ were then incubated with $50 \mu \mathrm{l}$ substrate (400-lM Ac-DEVD-pNA) in $40 \mu \mathrm{l}$ assay buffer at $37^{\circ} \mathrm{C}$. Absorbances at $405 \mathrm{~nm}$ were read at several time-points for each sample. pNA concentrations in samples were determined using a standard plot of absorbance vs. pNA concentration. zVAD-fmk (Calbiochem; EMD Millipore, Billerica, MA, USA) was used as the pan-caspase inhibitor.

Measurement of ROS production. ROS generation in MCF-7 cells was quantified using 2',7'-dichlorodihydrofluorescein diacetate (DCF-DA; Molecular Probes; Thermo Fisher Scientific, Inc.). Briefly, following the various pharmacological treatments, cells were treated with $10 \mu 1$ DCF-DA at $37^{\circ} \mathrm{C}$ for $30 \mathrm{~min}$ and washed with PBS. Fluorescence was measured using a FACScan system (BD Biosciences) at excitation/emission wavelengths of $488 / 525 \mathrm{~nm}$.

Statistical analysis. Data are expressed as the mean \pm standard error. One-way analysis of variation followed by Tukey's post hoc test was used for multiple comparisons. The statistical analysis was performed using Prism version 6.0 (GraphPad Software Inc., La Jolla, CA, USA) and Origin version 8.0 (OriginLab, Northampton, MA, USA) software. $\mathrm{P}<0.05$ was considered to indicate a statistically significant difference.

\section{Results}

Identification of standard compounds in SBGE. Baicalin and wogonin were detected on the HPLC chromatogram of SBGE at retention times of 7.5 and $12.5 \mathrm{~min}$, respectively (Fig. 1).

Apoptosis by SBGE in MCF-7 cells. To determine whether SBGE suppresses MCF-7 cell growth, MTT assays were performed following the culture for $24 \mathrm{~h}$ of cells containing different concentrations of SBGE. Cell viabilities were identified to be markedly reduced by SBGE treatment. Culture for $24 \mathrm{~h}$ in the presence of $100,200,300$ or $500 \mu \mathrm{g} / \mathrm{ml}$ of SBGE in culture medium inhibited cell survival by $33.7 \pm 7.3,78.4 \pm 5.4$, $81.4 \pm 4.5$ and $85.5 \pm 7.0 \%$, respectively, as determined by MTT assay ( $\mathrm{n}=5$; Fig. $2 \mathrm{~A}$ ). In addition, to determine whether SBGE induces apoptosis, cell cycle and mitochondrial membrane potential analysis were conducted by flow cytometry and fluorescence microscopy, respectively. Cells were treated with SBGE for $24 \mathrm{~h}$ (at concentrations between 100 and $500 \mu \mathrm{g} / \mathrm{ml}$; Fig. 2B and C). The sub-G1 phase ratio was significantly and dose-dependently increased by SBGE. More specifically, the sub-G1 phase was markedly increased by $6.2 \pm 2.1 \%$ at $100 \mu \mathrm{g} / \mathrm{ml}, 13.3 \pm 3.5 \%$ at $200 \mu \mathrm{g} / \mathrm{ml}, 17.8 \pm 4.1 \%$ at $300 \mu \mathrm{g} / \mathrm{ml}$ and $57.1 \pm 6.2 \%$ at $500 \mu \mathrm{g} / \mathrm{ml}$ compared with untreated cells $(n=5$; Fig. 2B). In addition, mitochondrial membrane potentials were suppressed by SBGE. SBGE-induced mitochondrial membrane potential was decreased by $18.5 \pm 11.3 \%$ at $100 \mu \mathrm{g} / \mathrm{ml}, 21.7 \pm 7.7 \%$ at $200 \mu \mathrm{g} / \mathrm{ml}, 39.5 \pm 11.6 \%$ at $300 \mu \mathrm{g} / \mathrm{ml}$ and $48.2 \pm 8.0 \%$ at $500 \mu \mathrm{g} / \mathrm{ml}$ compared with untreated cells $(\mathrm{n}=5$; Fig. 2C). These results suggested that SBGE has an anti-cancer effect and that this effect is closely associated with apoptotic induction.

SBGE induces apoptosis via a mitochondrial- and caspase-dependent signaling pathway in MCF-7 cells. To determine whether SBGE-induced MCF-7 cell apoptosis is regulated by Bcl-2 (anti-apoptotic) and Bax (pro-apoptotic), western blotting was used following the exposure of the cells to various concentrations (between 100 and $500 \mu \mathrm{g} / \mathrm{ml}$ ) of SBGE for $24 \mathrm{~h}$. The results revealed that Bcl-2 expression was markedly inhibited by SBGE, whereas that of Bax was upregulated (Fig. 3A).

As the Fas/FasL system serves a key function in death receptor-mediated apoptosis, the involvement of the Fas/FasL/TNF- $\alpha$ system was examined in SBGE-treated cells by RT-PCR. The results demonstrated that Fas/FasL and TNF- $\alpha$ expression levels were unchanged by SBGE (Fig. 3B). In addition, as caspase activation is required for apoptosis, caspase activity assays were performed to assess the activities of caspases 3 and 9 in MCF-7 cells. It was identified that caspase activities were increased following treatment with SBGE (between 100 and $500 \mu \mathrm{g} / \mathrm{ml}$ ) for $24 \mathrm{~h}$, and that these activities were suppressed by zVAD-fmk (Fig. 3C). These results suggested that SBGE-induced apoptosis is mediated by a mitochondrial- and caspase-dependent signaling pathway in MCF-7 cells.

SBGE induces apoptosis via the c-Jun N-terminal kinase (JNK) and MAPK signaling pathway in MCF-7 cells. To investigate the association between the regulation of MAPK 

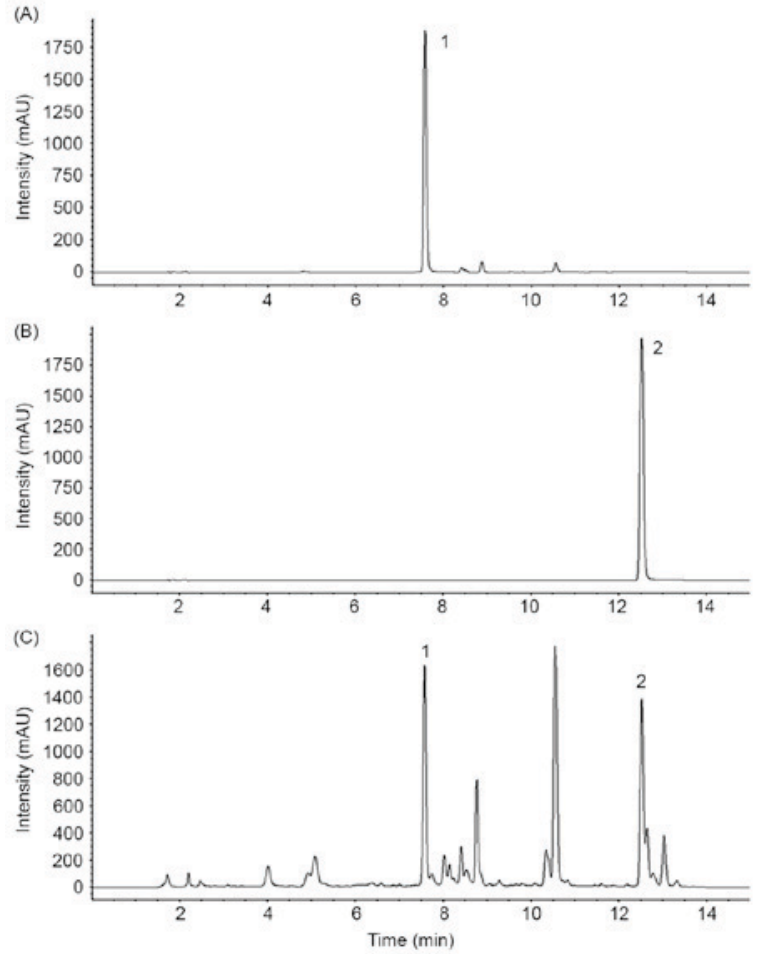

Figure 1. High performance liquid chromatography chromatograms of (A) baicalin and (B) wogonin, and of (C) Scutellaria baicalensis Georgi extract at a wavelength of $280 \mathrm{~nm}$. 1, baicalin; 2, wogonin.

pathways and the inhibition of MCF-7 cell proliferation by SBGE, cell viabilities were measured following the treatment of cells with SBGE at various concentrations (between 100 and $500 \mu \mathrm{g} / \mathrm{ml}$ ) for $24 \mathrm{~h}$ with or without SP600125 (a JNK inhibitor) or PD98059 (a MAPK inhibitor) using the MTT assay. Co-treatment with $10 \mu \mathrm{M}$ SP600125 or PD98059 markedly inhibited SBGE-induced cell death, particularly when cells were co-treated with $200 \mu \mathrm{g} / \mathrm{ml} \mathrm{SBGE}$. More specifically, co-treatment with $100,200,300$ or $500 \mu \mathrm{g} / \mathrm{ml} \mathrm{SBGE}$ and SP600125 inhibited cell survival by $7.9 \pm 3.5,19.5 \pm 4.9$, $34.2 \pm 2.8$ and $48.7 \pm 3.5$, respectively, as determined by the MTT assay (n=6; Fig. 4A). Co-treatment with 100, 200, 300 or $500 \mu \mathrm{g} / \mathrm{ml}$ of SBGE and PD98059 in culture medium inhibited cell survival by $6.4 \pm 2.8,21.1 \pm 3.5,34.8 \pm 2.7$ and $46.4 \pm 4.5 \%$, respectively ( $n=6$; Fig. $4 \mathrm{~B})$. These results suggested that JNK and MAPK are involved in SBGE-induced apoptosis of MCF-7 cells.

SBGE-induced apoptosis is mediated by the generation of intracellular ROS in MCF-7 cells. AS intracellular ROS serve a key role in apoptosis, whether SBGE is able to generate ROS in MCF-7 cells was studied. To investigate whether ROS generation was directly associated with SBGE-induced apoptosis, intracellular ROS were investigated using the fluorescent dye DCF-DA. As indicated in Fig. 5A, when the cells were exposed to SBGE, levels of intracellular ROS increased. Furthermore, when cells were treated with various concentrations (between 100 and $500 \mu \mathrm{g} / \mathrm{ml}$ ) of SBGE for $24 \mathrm{~h}$, ROS generation significantly and dosedependently increased, as demonstrated by flow cytometry (Fig. 5B).

\section{Discussion}

SBG is used as medicinal plant in traditional herbal medicine, particularly in China (22). The major materials isolated from S. baicalensis are flavonoids, glycosides and the glucuronides of flavonoids, including baicalin, baicalein and wogonin. (22). Certain flavonoids possess various pharmacological activities, including anti-oxidant, anti-apoptotic, anti-allergic and anti-inflammatory effects (22-24). In addition, S. baicalensis and its flavonoids have been demonstrated to exhibit anticancer effects in various types of cancer cells (11-15,25-30). Although it has been reported that $S$. baicalensis inhibits the proliferations of several cancer cell lines in vitro (11-15,25-30), its anti-cancer activity and associated mechanisms in human breast adenocarcinoma MCF-7 cells remain unclear. Therefore, the present study investigated the underlying mechanisms of this phenomenon and identified SBGE-induced apoptotic signaling via mitochondrial- and caspase-dependent pathways via ROS generation in human breast cancer cells.

Apoptosis can be initiated through two signaling pathways: Extrinsic (death receptor-mediated) and intrinsic (mitochondria-mediated) pathways $(31,32)$. The extrinsic pathway is initiated by extracellular signals, including FasL (33). The intrinsic pathway is regulated by Bcl-2 family proteins (anti-apoptotic proteins) (34). Notably, Bax protein shares regions of homology with Bcl-2 $(35,36)$. Additionally, the downregulation of $\mathrm{Bcl}-2$ proteins and the upregulation of Bax proteins may induce the destruction of the mitochondrial outer membrane (37-39). The caspases are major executors of apoptotic processes and belong to a group of enzymes called cysteine proteases (40). In the current study, Bcl-2 expression was inhibited by SBGE, whereas Bax expression was upregulated. However, Fas/FasL and TNF- $\alpha$ expression levels were unchanged, which suggested that SBGE induces cell death via the intrinsic pathway in MCF-7 human breast cancer cells. There are a number of breast cancer cell line types including, MCF-7, HBL100, MDAMB231, BT-20 and SKBR3 (41). In the present study, however, the effects of SBGE were investigated only in MCF-7 cells. The authors are now investigating the effects of SBGE on other breast cancer cell line types.

Transient receptor potential (TRP) channels were first cloned from Drosophila species and constitute a superfamily of proteins that encode a diverse group of $\mathrm{Ca}^{2+}$-permeable nonselective cation channels (NSCCs) $(42,43)$. Among the TRP channels, TRP melastatin type 7 (TRPM7) channel expression is essential for cell survival in breast adenocarcinoma cells and thus is also a potential therapeutic target in breast cancer (44). Therefore, the effects of SBGE on TRPM7 channels were investigated. However, no effects were observed on overexpressed TRPM7 channels (data not shown). Thus, it is hypothesized that the TRPM7 channel is not involved in SBGE-induced anti-cancer effects in MCF-7 cells.

A number of cancer-associated components of the MAPK signaling pathways have been identified in Ras and B-Raf, which participate in the extracellular signal regulated kinase (ERK) signaling pathway $(45,46)$. This kinase cascade presents novel opportunities for the development of novel cancer therapies designed to be less toxic than conventional chemotherapeutic drugs (47). The ERK signaling pathway serves a function in several steps of tumor development and also 

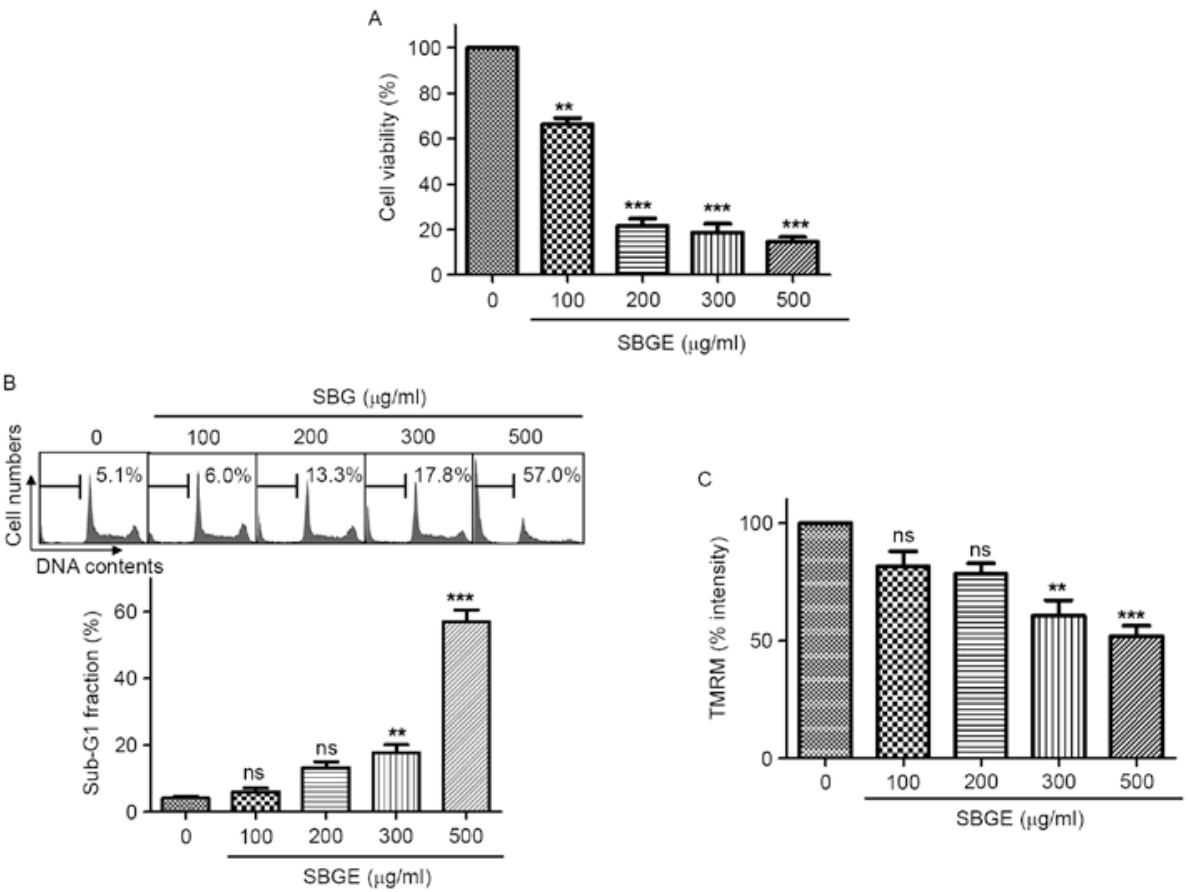

Figure 2. Induction of apoptosis in MCF-7 cells by SBGE. (A) Cell viabilities were determined by MTT assay. SBGE was identified to significantly and dose-dependently reduce cell viabilities for $24 \mathrm{~h}$. Numbers of viable cells following SBGE treatment are expressed as percentages of untreated cells. (B) Flow cytometry was used to investigate sub-G1 DNA contents. Cells were treated with the indicated concentrations of SBGE for $24 \mathrm{~h}$. Sub-G1 fractions are expressed as percentages. (C) Mitochondrial membrane potentials are expressed as percentages of untreated cells. Cells were treated with the indicated concentrations of SBGE for $24 \mathrm{~h}$. Data are presented as the mean \pm standard error. ${ }^{* *} \mathrm{P}<0.01,{ }^{* * * *} \mathrm{P}<0.001$ vs. untreated cells. SBGE, Scutellaria baicalensis Georgi extract; ns, not significant; TMRM, Tetramethylrhodamine.

A



B



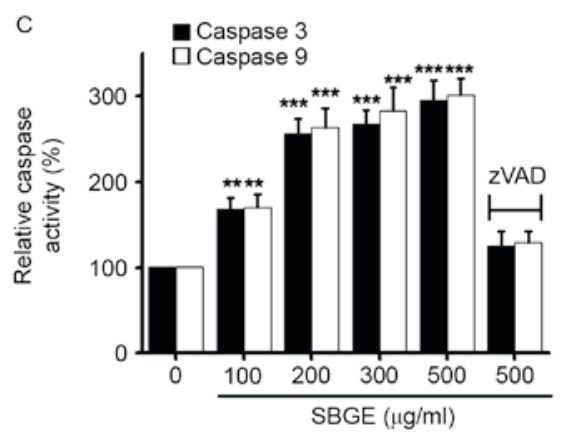

Figure 3. Bcl-2 protein downregulation, Bax protein upregulation and caspases 3 and 9 activities in MCF-7 cells. (A) Western blot analysis was performed on MCF-7 cells treated with different SBGE concentrations for $24 \mathrm{~h}$. Bcl-2 expression was downregulated by SBGE, whereas Bax expression was upregulated. (B) RT-PCR was performed on MCF-7 cells treated with different SBGE concentrations for $24 \mathrm{~h}$. The expression levels of Fas, FasL and TNF- $\alpha$ were unaffected by SBGE. (C) Caspase assays were conducted following the indicated SBGE concentrations for cells cultured for $24 \mathrm{~h}$. The caspase activity of untreated cells was taken to be $100 \%$. Cells were treated with $20 \mu \mathrm{M}$ zVAD-fm as a pan-caspase inhibitor. Data are presented as the mean \pm standard error. ${ }^{* *} \mathrm{P}<0.01,{ }^{* * *} \mathrm{P}<0.001$ vs. untreated cells. GAPDH and $\beta$-actin served as a loading control. Bcl-2, B-cell lymphoma 2; Bax, Bcl-2 X-associated protein; SBGE, Scutellaria baicalensis Georgi extract; RT-PCR, reverse transcription-polymerase chain reaction; FasL, Fas ligand; TNF, tumor necrosis factor.

induces the expression of matrix metalloproteinases, thereby promoting the degradation of extracellular matrix proteins and consequent tumor invasion (48). Therefore, components of signaling pathways activated by MAPK have received great attention as potential targets for the development of novel therapeutic drugs for cancer (49). 
A



B



Figure 4. Effect of SBGE on the MAPK signaling pathway in MCF-7 cells. An MTT assay was used to determine cell viabilities in the presence of (A) SP600125 (a JNK inhibitor) or (B) PD98059 (a MAPK inhibitor). Cells were co-treated with the indicated concentrations of SBGE plus SP600125 or PD98059 (10 $\mu$ M) for $24 \mathrm{~h}$. Data are presented as the mean \pm standard error. ${ }^{* * *} \mathrm{P}<0.01,{ }^{* * * *} \mathrm{P}<0.001$ vs. untreated cells. ${ }^{*} \mathrm{P}<0.05$. SBGE, Scutellaria baicalensis Georgi extract; MAPK, mitogen-activated protein kinase; JNK, c-Jun N-terminal kinase.

A



B



Figure 5. SBGE enhances ROS accumulation in MCF-7 cells. (A) To assess ROS production, cells were stained with DCF-DA and intracellular ROS levels were measured by flow cytometry. (B) Intracellular ROS was detected in MCF-7 cells treated with the indicated concentrations of SBGE for $24 \mathrm{~h}$. ROS levels are expressed as percentages of those of untreated cells. Data are presented as the mean \pm standard error. ${ }^{* * *} \mathrm{P}<0.01,{ }^{* * *} \mathrm{P}<0.001$ vs. untreated cells. Ns, not significant; SBGE, Scutellaria baicalensis Georgi extract; ROS, reactive oxygen species; DCF-DA, 2',7'-dichlorodihydrofluorescein diacetate.

There is considerable interest among oncologists to find anticancer drugs in TCM. In the past, clinical data demonstrated that certain herbs possessed anticancer properties $(50,51)$; however, western scientists have doubted the validity of TCM due to the lack of scientific evidence (52). Recently, experiments have demonstrated that elements of TCM may possess an anticancer role, and clinical trials have demonstrated that TCM could improve survival, increase tumor response, improve the quality of life and reduce chemotherapy toxicity (52-56). Therefore, the authors of the present study suggest that when combined with chemotherapy, TCM could raise the efficacy level and lower toxic reactions.
In conclusion, the present study demonstrated that SBGE induces Bcl-2 protein downregulation and Bax protein upregulation, and activates caspases 3 and 9, leading to apoptosis. It was also identified that SBGE-induced cell death depends on the ROS-mediated JNK/MAPK signaling pathway. Therefore, SBEG may cause cell death via the intrinsic pathway in human breast cancer MCF-7 cells. These findings implicate SBEG as a useful potential anticancer agent.

\section{Acknowledgements}

The present study was supported by a Korean National Research Foundation (NRF) Grant funded by the Korean Government (MSIP; grant no. 2014R1A5A2009936).

\section{References}

1. Weigelt B, Peterse JL and van't Veer LJ: Breast cancer metastasis: Markers and models. Nat Rev Cancer 5: 591-602, 2005.

2. Van Pham P: Breast Cancer Stem Cells \& Therapy Resistance. Springer. Berlin, Germany, 2015.

3. Stewart B and Wild C: World Cancer Report 2014. In International Agency for Research on Cancer. World Health Organization, Geneva, Switzerland, 2014.

4. Torre LA, Bray F, Siegel RL, Ferlay J,Lortet-Tieulent J and Jemal A: Global cancer statistics, 2012. CA Cancer J Clin 65: 87-108, 2015.

5. Bartsch R, Wenzel C and Steger GG: Trastuzumab in the management of early and advanced stage breast cancer. Biologics 1: 19-31, 2007.

6. Vici P, Colucci G, Gebbia V, Amodio A, Giotta F, Belli F, Conti F, Gebbia N, Pezzella G, Valerio MR, et al: First-line treatment with epirubicin and vinorelbine in metastatic breast cancer. J Clin Oncol 20: 2689-2694, 2002.

7. Li W, Li C, Zheng H, Chen G and Hua B: Therapeutic targets of traditional Chinese medicine for colorectal cancer. J Tradit Chin Med 36: 243-249, 2016.

8. Li HL: Research progress of Scutellaria baicalensis. Chem Eng Equip 4: 100-102,2008

9. Zhang L, Ravipati AS, Koyyalamudi SR, Jeong SC, Reddy N, Smith PT, Bartlett J, Shanmugam K, Münch G and Wu MJ: Antioxidant and anti-inflammatory activities of selected medicinal plants containing phenolic and flavonoid compounds. J Agric Food Chem 59: 12361-12367, 2011.

10. Kim HP, Son KH, Chang HW and Kang SS: Anti-inflammatory plant flavonoids and cellular action mechanisms. J Pharmacol Sci 96: 229-245, 2004.

11. Choi EO, Park C, Hwang HJ, Hong SH, Kim GY, Cho EJ, Kim WJ and Choi YH: Baicalein induces apoptosis via ROS-dependent activation of caspases in human bladder cancer 5637 cells. Int J Oncol 49: 1009-1018, 2016. 
12. Choi EO, Cho EJ, Jeong JW, Park C, Hong SH, Hwang HJ, Moon SK, Son CG, Kim WJ and Choi YH: Baicalein inhibits the migration and invasion of B16F10 mouse melanoma cells through inactivation of the PI3K/Akt signaling pathway. Biomol Ther (Seoul) 25: 2013-221, 2017.

13. Yan H, Xin S, Wang H, Ma J, Zhang $\mathrm{H}$ and Wei H: Baicalein inhibits MMP-2 expression in human ovarian cancer cells by suppressing the $\mathrm{p} 38 \mathrm{MAPK}$-dependent $\mathrm{NF}-\mathrm{\kappa B}$ signaling pathway. Anticancer Drugs 26: 649-656, 2015.

14. Chung H, Choi HS, Seo EK, Kang DH and Oh ES: Baicalin and baicalein inhibit transforming growth factor- $\beta 1$-mediated epithelial-mesenchymal transition in human breast epithelial cells. Biochem Biophys Res Commun 458: 707-713, 2015.

15. Kim SD, Lee YJ, Baik JS, Han JY, Lee CG, Heo K, Park YS Kim JS, Ji HD, Park SI, et al: Baicalein inhibits agonist- and tumor cell-induced platelet aggregation while suppressing pulmonary tumor metastasis via cAMP-mediated VASP phosphorylation along with impaired MAPKs and PI3K-Akt activation. Biochem Pharmacol 92: 251-265, 2014.

16. Elmore S: Apoptosis: A review of programmed cell death. Toxicol Pathol 35: 495-516, 2007.

17. Saraste A and Pulkki K: Morphologic and biochemical hallmarks of apoptosis. Cardiovasc Res 45: 528-537, 2000.

18. Wong RS: Apoptosis in cancer: From pathogenesis to treatment J Exp Clin Cancer Res 30: 87, 2011.

19. Kuno T, Tsukamoto T, Hara A and Tanaka T: Cancer chemoprevention through the induction of apoptosis by natural compounds. J Biophys Chem 3: 156-173, 2012.

20. Nicoletti I, Migliorati G, Pagliacci MC, Grignani F and Riccardi C: A rapid and simple method for measuring thymocyte apoptosis by propidium iodide staining and flow cytometry. J Immunol Methods 139: 271-279, 1991.

21. Wang BJ, Won SJ, Yu ZR and Su CL: Free radical scavenging and apoptotic effects of cordycepin sinensis ractionated by supercritical carbon dioxide. Food Chem Toxicol 43: 543-552, 2005.

22. Gaire BP, Moon SK and Kim H: Scutellaria baicalensis in stroke management: Nature's blessing in traditional Eastern medicine. Chin J Integr Med 20: 712-720, 2014.

23. Chen WP, Xiong Y, Hu PF, Bao JP and Wu LD: Baicalein inhibits MMPs expression via a MAPK-dependent mechanism in chondrocytes. Cell Physiol Biochem 36: 325-333, 2015.

24. Li C, Lin G and Zuo Z: Pharmacological effects and pharmacokinetics properties of Radix Scutellariae and its bioactive flavones. Biopharm Drug Dispos 32: 427-445, 2011.

25. Lee HZ, Leung HW, Lai MY and Wu CH: Baicalein induced cell cycle arrest and apoptosis in human lung squamous carcinoma CH27 cells. Anticancer Res 25: 959-964, 2005.

26. Kim SJ, Kim HJ, Kim HR, Lee SH, Cho SD, Choi CS, Nam JS and Jung JY: Antitumor actions of baicalein and wogonin in HT-29 human colorectal cancer cells. Mol Med Rep 6: 1443-1449, 2012.

27. Li HL, Zhang S, Wang Y, Liang RR, Li J, An P, Wang ZM, Yang J and Li ZF: Baicalein induces apoptosis via a mitochondrial-dependent caspase activation pathway in T24 bladder cancer cells. Mol Med Rep 7: 266-270, 2013.

28. Wang Z, Jiang C, Chen W, Zhang G, Luo D, Cao Y, Wu J, Ding Y and Liu B: Baicalein induces apoptosis and autophagy via endoplasmic reticulum stress in hepatocellular carcinoma cells. Biomed Res Int 2014: 732516, 2014

29. Liu-Smith F and Meyskens FL: Molecular mechanisms of flavonoids in melanin synthesis and the potential for the prevention and treatment of melanoma. Mol Nutr Food Res 60: 1264-1274, 2016.

30. Mu J, Liu T, Jiang L, Wu X, Cao Y, Li M, Dong Q, Liu Y and $\mathrm{Xu}$ H: The traditional Chinese medicine baicalein potently inhibits gastric cancer cells. J Cancer 7: 453-461, 2016.

31. Thompson CB: Apoptosis in the pathogenesis and treatment of disease. Science 267: 1456-1462, 1995.

32. Adams JM and Cory S: The Bcl-2 apoptotic switch in cancer development and therapy. Oncogene 26: 1324-1337, 2007.

33. Wajant $\mathrm{H}$ : The Fas signaling pathway: More than a paradigm. Science 296: 1635-1636, 2002

34. Cory S and Adams JM: The Bcl2 family: Regulators of the cellular life-or-death switch. Nat Rev Cancer 2: 647-656, 2002.

35. Moldoveanu T, Liu Q, Tocilj A, Watson M, Shore G and Gehring K: The X-ray structure of a BAK homodimer reveals an inhibitory zinc binding site. Mol Cell 24: 677-688, 2006.
36. Suzuki M, Youle RJ and Tjandra N: Structure of Bax: Coregulation of dimer formation and intracellular localization. Cell 103: 645-654, 2000.

37. Green SR and Reed JC: Mitochondria and apoptosis. Science 281: 1309-1312, 1998

38. Jeong SY and Seol DW: The role of mitochondria in apoptosis. BMB Rep 41: 11-22, 2008.

39. Spierings D, McStay G, Saleh M, Bender C, Chipuk J, Maurer U and Green DR: Connected to death: The (unexpurgated) mitochondrial pathway of apoptosis. Science 310: 66-67, 2005

40. Earnshaw WC, Martins LM and Kaufmann SH: Mammalian caspases: Structure, activation, substrates, and functions during apoptosis. Annu Rev Biochem 68: 383-424, 1999.

41. Neve RM, Chin K, Fridlyand J, Yeh J, Baehner FL, Fevr T, Clark L, Bayani N, Coppe JP, Tong F, et al: A collection of breast cancer cell lines for the study of functionally distinct cancer subtypes. Cancer Cell 10: 515-527, 2006.

42. Kim HJ, Wie J, So I, Jung MH, Ha KT and Kim BJ: Menthol modulates pacemaker potentials through TRPA1 channels in cultured interstitial cells of cajal from murine small intestine. Cell Physiol Biochem 38: 1869-1882, 2016.

43. Kim BJ, Lee GS and Kim HW: Involvement of transient receptor potential melastatin type 7 channels on Poncirus fructus-induced depolarizations of pacemaking activity in interstitial cells of Cajal from murine small intestine. Integr Med Res 2: 62-69, 2013

44. Guilbert A, Gautier M, Dhennin-Duthille I, Haren N, Sevestre H and Ouadid-Ahidouch H: Evidence that TRPM7 is required for breast cancer cell proliferation. Am J Physiol Cell Physiol 297: C493-C502, 2009.

45. Dhillon AS, Hagan S, Rath O and Kolch W: MAP kinase signalling pathways in cancer. Oncogene 26: 3279-3290, 2007.

46. Boutros T, Chevet E and Metrakos P: Mitogen-activated protein (MAP) kinase/MAP kinase phosphatase regulation: Roles in cell growth, death, and cancer. Pharmacol Rev 60: 261-310, 2008.

47. Sebolt-Leopold JS: Development of anticancer drugs targeting the MAP kinase pathway. Oncogene 19: 6594-6599, 2000.

48. Chakraborti S, Mandal M, Das S, Mandal A and Chakraborti T: Regulation of matrix metalloproteinases: an overview. Mol Cell Biochem 253: 269-285, 2003.

49. Kim EK and Choi EJ: Pathological roles of MAPK signaling pathways in human diseases. Biochim Biophys Acta 1802: 396-405, 2010

50. Cheng YL, Chang WL, Lee SC, Liu YG, Lin HC, Chen CJ, Yen CY, Yu DS, Lin SZ and Harn HJ: Acetone extract of Bupleurum scorzonerifolium inhibits proliferation of A549 human lung cancer cells via inducing apoptosis and suppressing telomerase activity. Life Sci 73: 2383-2394, 2003.

51. Wartenberg M, Budde P, de Mareés M, Grünheck F, Tsang SY, Huang Y, Chen ZY, Hescheler J and Sauer H: Inhibition of tumor-induced angiogenesis and matrix-metalloproteinase expression in confrontation cultures of embryoid bodies and tumor spheroids by plant ingredients used in traditional chinese medicine. Lab Invest 83: 87-98, 2003.

52. Ruan WJ, Lai MD and Zhou JG: Anticancer effects of Chinese herbal medicine, science or myth? J Zhejiang Univ Sci B 7: 1006-1014, 2006.

53. Mabed M, El-Helw L and Shamaa S: Phase II study of viscum fraxini-2 in patients with advanced hepatocellular carcinoma. $\mathrm{Br}$ J Cancer 90: 65-69, 2004

54. Shen ZX, Shi ZZ, Fang J, Gu BW, Li JM, Zhu YM, Shi JY, Zheng PZ, Yan H, Liu YF, et al: All-trans retinoic acid/As2O3 combination yields a high quality remission and survival in newly diagnosed acute promyelocytic leukemia. Proc Natl Acad Sci USA 101: 5328-5335, 2004

55. Piao BK, Wang YX, Xie GR, Mansmann U, Matthes H, Beuth J and Lin HS: Impact of complementary mistletoe extract treatment on quality of life in breast, ovarian and non-small cell lung cancer patients. A prospective randomized controlled clinical trial. Anticancer Res 24: 303-309, 2004.

56. Yan X, Shen H, Jiang H, Hu D, Zhang C, Wang J and Wu X: External Qi of Yan Xin Qigong Induces apoptosis and inhibits migration and invasion of estrogen-independent breast cancer cells through suppression of Akt/NF-kB signaling. Cell Physiol Biochem 25: 263-270, 2010. 